\title{
(Epi)genetic Modifications in Myogenic Stem Cells: From Novel Insights to Therapeutic Perspectives
}

\author{
Natacha Breuls ${ }^{1}$, Giorgia Giacomazzi ${ }^{1}$ and Maurilio Sampaolesi ${ }^{1,2, *(1)}$ \\ 1 Translational Cardiomyology Lab, Department of Development and Regeneration, Stem Cell Institute \\ Leuven, 3000 KU Leuven, Belgium; natacha.breuls@kuleuven.be (N.B.); Giorgia.Giacomazzi@ieo.it (G.G.) \\ 2 Human Anatomy Unit, Department of Public Health, Experimental and Forensic Medicine, \\ and Interuniversity Institute of Myology, University of Pavia, 27100 Pavia, Italy \\ * Correspondence: maurilio.sampaolesi@kuleuven.be or sampa@unipv.it
}

Received: 9 April 2019; Accepted: 7 May 2019; Published: 9 May 2019

\begin{abstract}
The skeletal muscle is considered to be an ideal target for stem cell therapy as it has an inherent regenerative capacity. Upon injury, the satellite cells, muscle stem cells that reside under the basal lamina of the myofibres, start to differentiate in order to reconstitute the myofibres while maintaining the initial stem cell pool. In recent years, it has become more and more evident that epigenetic mechanisms such as histon modifications, DNA methylations and microRNA modulations play a pivatol role in this differentiation process. By understanding the mechanisms behind myogenesis, researchers are able to use this knowledge to enhance the differentiation and engraftment potential of different muscle stem cells. Besides manipulation on an epigenetic level, recent advances in the field of genome-engineering allow site-specific modifications in the genome of these stem cells. Combining epigenetic control of the stem cell fate with the ability to site-specifically correct mutations or add genes for further cell control, can increase the use of stem cells as treatment of muscular dystrophies drastically. In this review, we will discuss the advances that have been made in genome-engineering and the epigenetic regulation of muscle stem cells and how this knowledge can help to get stem cell therapy to its full potential.
\end{abstract}

Keywords: epigenetics; skeletal muscle; genome-engeneering; stem cell therapy

\section{Introduction}

The skeletal muscle accounts for $\sim 40 \%$ of the human body weight and is important for movement and stability. Each muscle is composed of multinucleated myofibres, which are formed through the fusion of myoblasts during development. During embryogenesis, the skeletal muscle originates from paraxial mesoderm, part of the mesoderm located at the posterior part of the embryo. At the posterior tip of the embryo, the paraxial mesoderm starts to condense into somites progressively from head to tail. The newly formed somites will then adopt a sclerotomal (ventral) or dermomyotomal (dorsal) fate. Afterwards, the central part of the dermomyotome, defined by paired box gene 3 (Pax3) expression, disintegrates and the muscle progenitors start to give rise to the myotome [1,2]. When myogenesis begins, Pax3 is downregulated and specific basic helix-loop-helix transcription factors, known as muscle regulatory factors (MRFs), are sequentially upregulated. Myogenic factor 5 (Myf5) and subsequently muscle determining factor (MyoD), known as muscle determination genes, are upregulated after migration into the myotome, resulting in the myogenic determination of the precursor cells. Afterwards, myoblast differentiation is mainly led by Myogenin [3] (Figure 1A). 
A

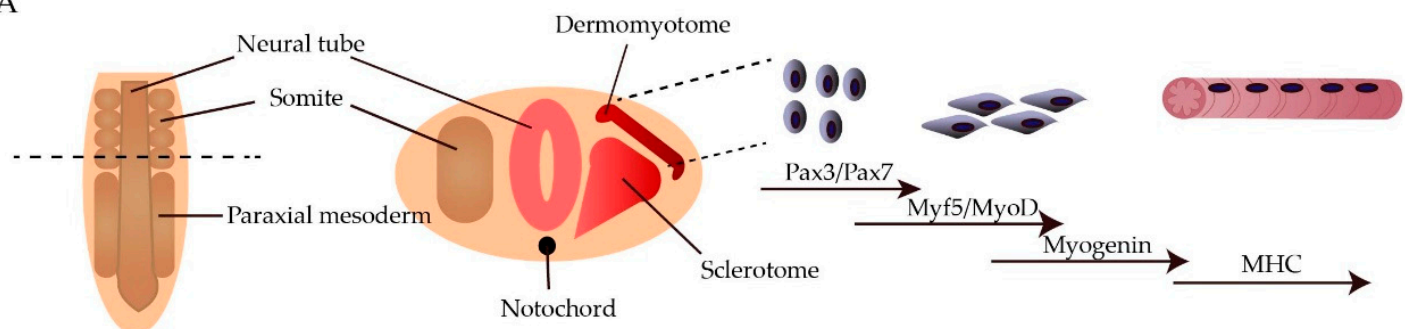

B

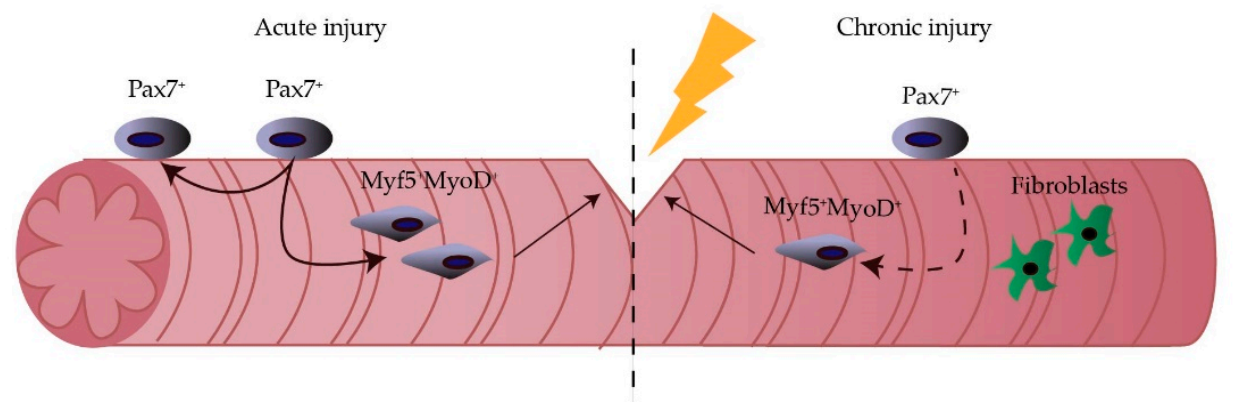

Figure 1. Myogenesis during embryonic development and adult life. During embryogenesis, the skeletal muscle originates from the paraxial mesoderm, which will further subdivide into somites. In the somites, $\mathrm{Pax}^{+} / \mathrm{Pax}^{+}$cells will arise from the dermomyotome and will form muscle fibers through the sequential upregulation of Myf5, MyoD and myosin heavy chain (MHC) (A). During adult life, Pax7 $7^{+}$ satellite cells are the main cell type responsible for muscle regeneration upon injury. However, when the injury is of chronic nature, this stem cell pool becomes exhausted and fibroblast are recruited to form scar tissue (B).

During adult life, in vivo myogenesis is mainly regulated by satellite cells (SCs), myogenic progenitors that reside under the basal lamina of the muscle fibres in a mitotically quiescent state. These SCs express Pax7, an analogue of Pax3, important for the persistence of the SC pool during post-natal life. Upon injury, the SCs become active and start to differentiate through the sequential expression of Myf5, MyoD and Myogenin (Figure 1B). This ability to incorporate mononucleated myoblasts into the multinucleated fibres makes the skeletal muscle an ideal target for stem cell therapy [4-6]. In fact, when a genetically corrected stem cell fuses with the existing myotube, this feature will be transferred within the long multinucleated syncytial tissue.

Muscular dystrophies (MDs) are a group of neuromuscular disorders, primarily characterized by progressive muscle weakening. Most of these disorders are caused by a single mutation within the dystrophin-associated glycoprotein complex. This complex normally serves as a mechanical link between the cytoskeleton and the laminin of the extracellular matrix, thereby stabilising the fibres upon muscle contraction. A mutation leading to the absence or dysfunction of one of these proteins, renders the sarcolemma vulnerable to contraction-induced damage, further leading to progressive fibre damage [7]. The most common type is Duchenne MD (DMD), a childhood MD caused by a mutation in the dystrophin gene. So far, therapy is focussed on the amelioration of symptoms rather than treatment of the disease $[8,9]$. Due to the chronic nature of MD, the endogenous stem cell pool becomes exhausted (Figure 1B). Therefore, patients could benefit from stem cell therapy to replenish the stem cell pool and regenerate the muscle.

The first stem cell pools considered to reconstitute the skeletal muscle are myoblasts or SCs, responsible for muscle regeneration in a physiological setting. Although they have the inherent capacity to reconstitute the muscle fibres, these stem cells lose their engraftment potential rapidly when they are cultured ex vivo. Furthermore, these cells lack migratory capacity causing the need for high-density cell injections at multiple sites to reach significant engraftment $[10,11]$. Another inherent 
stem cell is the mesoangioblast (MAB), a vessel-associated stem cell that can differentiate into all tissues of mesodermal origin [12]. MABs have the benefit that they can migrate into the muscle once they are injected into the bloodstream. However, despite encouraging preclinical results, clinical trials failed to show any functional improvement so far, suggesting that there is room to enhance the myogenic potential of MABs [13-15].

A pool of stem cells that have gained interest in recent years are induced pluripotent stem cells (iPSCs). These cells have the benefit that they possess an unlimited in vitro proliferative capacity and have the ability to differentiate into all cell types. Nevertheless, researchers are still struggling to obtain a pure myogenic population from iPSCs in order to avoid the risk of uncontrolled cell growth, once injected in vivo.

\section{Epigenetics}

In order to improve the potential of the aforementioned stem cells, strategies can be developed through the recent insights in the regulation of endogenous myogenesis. A recent topic that has received much attention is the epigenetic regulation of skeletal muscle regeneration. Epigenetics comprises all heritable mechanisms that do not affect the DNA sequence itself. These epigenetic marks can lie on the DNA itself (methylation) or on the histones surrounding the DNA (methylation, phosphorylation, acetylation and ubiquitination of their amino acid residues). These marks will influence the configuration of the chromatin. When the DNA is loosely wrapped around the histones, due to activation marks such as acetylations, genes can be transcribed. When repressive marks, such as DNA methylations, are present, gene transcription in these areas is blocked [16,17]. Another mechanism by which gene expression can be repressed is through the post-transcriptional binding of microRNAs (miRNAs) to the mRNA. All these epigenetic regulations have been implemented in myogenesis and can be used to manipulate the potential of muscle stem cells.

\subsection{Epigenetic Regulation of Myogenesis}

\subsubsection{DNA Methylation}

DNA Methylation introduces a methyl group to the cytosine residue, thereby causing steric hindrance, which prevents DNA-binding proteins from binding. The two groups of enzymes responsible for these methylations are the DNA methyltransferases (DNMTs) and the ten-eleven translocation methylcytosine dioxygenase (TET) family of proteins [18,19]. CpG islands, areas of the genome rich in cytosine residues followed by guanine residues, are considered regulatory regions for DNA methylation. Although not all promoters have CpG islands, the hypermethylation of these regions is associated with gene silencing. A study that described the methylome changes during myobalst development, has reported the occurrence of hypermethylation waves during skeletal muscle-lineage commitment. Those regions remained stably methylated, whereas muscle-regulatory regions, including the master gene Myf5, underwent hypomethylation to allow the onset of the myogenic differentiation program [20]. Global DNA methylation is increased during the progression from myoblasts to mature myotubes. Furthermore, myogenic stem cell activation and differentiation is marked by the upregulation of specific DNMT isoforms [21].

\subsubsection{Histone Methylation}

The chromatin is composed out of a chain of nucleosomes, which are, in turn, built up out of four histones- H2A, H2B, H3 and H4. The amino acid tails of these histones are subjected to various post-transcriptional changes, which can regulate gene expression or repression. Methylations of histons generally occours at the lysine and arginine residues at the N-terminals of H3 and H4. Methyl groups are transferred from S-adenosyl methionine to these residues by histone methyltransferases (HMTs) [22]. The marks most implicated during skeletal muscle development are the trimethylation of histone 3 
lysine $4(\mathrm{H} 3 \mathrm{~K} 4 \mathrm{~m} 3)$, associated with gene activation, and the trimethylation of histone 3 lysine 27 or lysine 9 (H3K27m3/H3K9m3), involved in gene repression.

In quiescent SCs, the Polycomb Repressive Complex 2 (PRC2) is expressed, resulting in the acquisition of $\mathrm{H} 3 \mathrm{~K} 27 \mathrm{~m} 3$ silencing marks throughout the genome [23-25]. In addition, the transcription start sites of Pax7, Myf5 and MyoD are marked by an H3K4m3. Although the methylation, as such, does not induce expression, it marks the genes for activation leading to a rapid transcriptional induction upon the right stimuli. Activation of the SCs is marked by an acquisition of the repressive H3K27m3, known to be dominant over the H3K4m3, at the level of Pax7. In contrast, H3K4m3 is enriched at the chromatin neighbouring MyoD and Myf5 [26-30]. Master regulator MyoD has been associated with several HMTs, thereby regulating the expression of downstream MRFs (Figure 1). For example, in activated SCs HMT G9a is recruited to MyoD by homeoprotein Msx1, leading to the enrichment of H3K9me2 marks [31,32]. Although G9a represses MyoD, its expression is not abolished completely (Figure 2A). When MyoD binds to the MRF promotors, co-binding with HTMs KMT1A and Suv39h1 prevents premature activation of myogenic genes by stimulating repressive histone marks (Figure 2B) [33-35]. Upon differentiation, MyoD can be recruited to the promoters of several MRFs through the increased accessibility caused by the SWItch/Sucrose NonFermentable (SWI/SNF) chromatin-remodelling complex [36,37]. Once differentiation is induced, MyoD together with HMTs Set7/9 and DN-JMJD2A, leads to the removal of repressive histone marks and the acquisition of H3K4m3 (Figure 2D) [38,39].

A

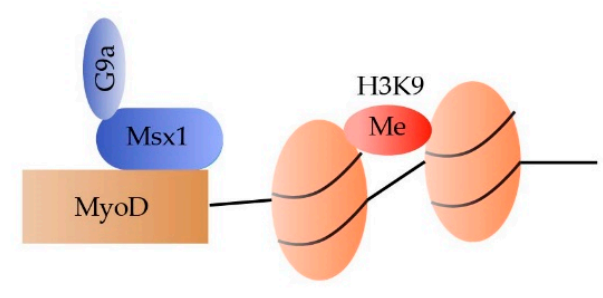

C

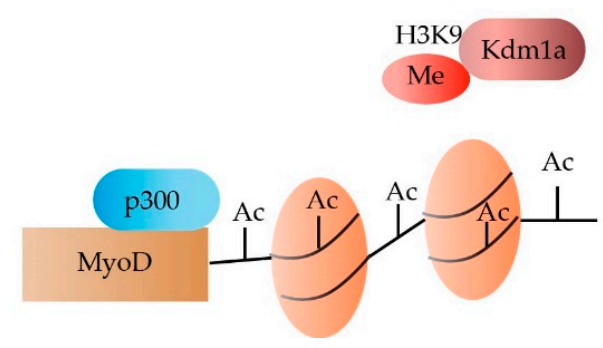

B

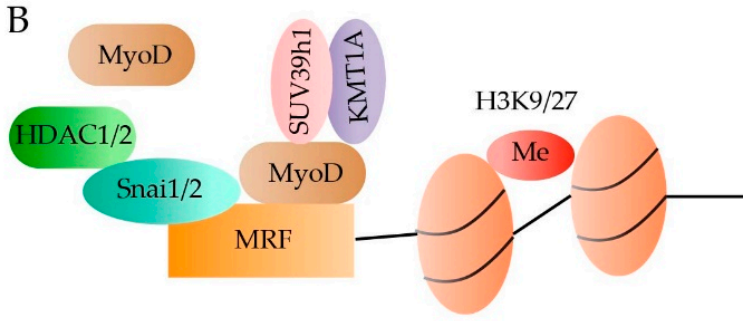

$\mathrm{D}$

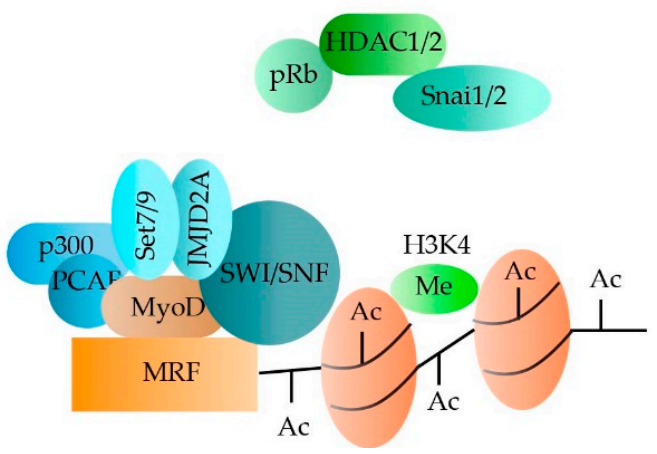

Figure 2. Epigenetic regulation of $\mathrm{MyoD}$ in the quiescent and activated satellite cells (SCs). MyoD is repressed in dormant SCs due to the presence of H3K9me2 marks, recruited by the Msx1/G9a complex (A). Furthermore, the binding of MyoD to the muscle regulatory factors (MRFs) through the binding of the Snai1/2:HDAC1/2 complex, renders the MRFs hypo-acetylated. The small amount of MyoD that binds to the MRFs will recruite SUV39h and KMT1A, leading to the addition of repressive H3K9/27m3 marks (B). Upon SC activation, repressive marks are removed from MyoD by Kdm1a and from the MRFs by phosphor-retinoblastoma (pRb). Furthermore, acetylation is increased by binding of p300 and pCAF (C,D). Once MyoD is activated, it will bind to the MRFs and recruit Set7/9, JMJD2A and SWI/SNF, which will add permissive H3K4m3 marks (D).

\subsubsection{Histone Acetylation}

Acetylation of the lysine residues on the histones neutralizes the positive charge, thereby relaxing the chromatin. By relaxing the chromatin, transcriptional binding sites become more accessible, leading 
to increased gene expression. In general, two types of enzymes control acetylation: the histone acetyltransferases (HATs) and the histone deacetylases (HDACs). The HDACs can be subdivided into four classes of which class $I$ is the most transcriptionally active. In dormant SCs, MyoD activity is prevented through the binding of repressor Snai1/2 to the promoters of multiple MRFs and the subsequent recruiting of HDAC 1 and 2, rendering the MRFs in a hypo-acetylated state (Figure 1B) [40,41]. Once the SCs become activated, the Snai1/2:HDAC1/2 complex is removed through binding of phosphor-retinoblastoma (pRb) [42]. In addition, HAT p300 acetylates both MyoD and the downstream MRFs when associated with pCAF (Figure 2A,D) [43,44].

\subsection{4. miRNAs}

miRNAs are 20-22 nucleotides long non-protein coding RNA molecules primarily involved in post-transcriptional gene regulation. The biogenesis of miRNAs starts in the nucleus, where miRNAs are generally transcribed by RNA polymerase II in primary transcripts called pre-miRs and subsequently cleaved by the microprocessor complex into shorter precursor molecules called pri-miRs. Pre-miRs are then transported into the cytosol, where they are further cleaved into $22 \mathrm{nt}$ long double-stranded molecules by a complex that includes a RNase-III, Dicer. miRNAs are then ready to be loaded on the RNA-induced silencing complex (RISC); the guide strand is loaded while the star strand is generally degraded [45]. miRNAs-mediated gene regulation is generally achieved via complementary binding of the single-stranded miRNA molecules to specific mRNA sequences, thus targeting mRNA for degradation. miRNAs are considered as epigenetic regulators since they primarily modulate protein level without modifying the gene sequences [46]. Additionally, miRNAs directly target epigenetic regulatory mechanisms, such as DNA methylation and histone modifications. miRNAs can, in fact, interfere with the epigenetic machinery by targeting DNMTs as they do in some types of cancers $[47,48]$, or by binding histone deacetylases HDAC1 and HDAC4 [49].

miRNAs are actively involved at various stages of embryonic and adult myogenesis. miRNAs are key players in tuning striated muscle formation, both at the early stages of development and by modulation of stem cells during adult life. A group of miRNAs, known as the myomiRs, have been characterized in depth and their role in orchestrating skeletal myogenesis is well established [50]. MiR-1 and miR-133 are the main members of the myomir family. Both these miRNAs intrinsically modulate proliferation and differentiation of skeletal muscle stem cell lineages, though the direct regulation of serum response factor (SRF) and myocyte enhancer factor 2(MEF2) [51]. Another well-known myogenic player is mir-206, a positive regulator of myogenesis by supporting SC differentiation and repressing many negative modulators of skeletal muscle differentiation [52]. Alongside the aforementioned miRNAs, several others have been described as dynamic players in myogenesis, such as miR-181, a broadly expressed miRNA, which contributes to myoblast differentiation by targeting a MyoD repressor in mammals [53], miR-24 and miR-27 [54,55]. Finally, miR-669a downregulation has been linked to the severe disease progression in sarcoglycan beta-null mice, a mouse model for limb girdle MD type 2E, and long-term overexpression of miR-669a improved significantly sarcoglycan beta-null muscle structure and functionality [56,57].

\subsection{Epigenetics to Skew Skeletal Muscle Differentiation}

Due to the increasing knowledge in epigenetic regulation of myogenesis, researchers started to consider the adaptation of epigenetic marks as a strategy to reprogram the stem cell fate. An initial strategy used is drugs that can specifically modulate the epigenome. These drugs have the benefit of already being in the clinic for many years for several cancers. A more novel strategy is the use of miRNAs to manipulate the gene expression.

\subsubsection{Epigenetic Drugs}

An initial strategy to manipulate the stem cell fate is through the use of epigenetic drugs. The first epigenetic drug used to manipulate the epigenetic state in myogenesis or MDs are the HDAC inhibitors 
(HDACi) [58]. HDACi have been proven to functionally and histologically restore the muscle fibres in several mouse models of MDs [59,60]. These beneficial outcomes have led to the start of a clinical trial to evaluate the effect of HDACi Givinostat in DMD patients [61]. So far, in phase I and II clinical trials, Givinostat is proven safe and counteracts the histological progression of DMD [62]. Currently, a phase III clinical trial is ongoing.

The effect on the muscle stem cells specifically, has mainly been investigated with Trichostatin A and valproic acid. More specifically, in vitro, these HDACi increase the fusion of $\mathrm{C} 2 \mathrm{C} 12$ myoblasts into myotubes [63]. Mechanistically, this effect is most probably mediated through the activation of MyoD and SNF/SWI complex protein Baf60c, leading to full epigenetic reprogramming [37,64]. In the case of valproic acid, this epigenetic reprogramming was even strong enough to induce myocyte differentiation from PSCs without the need for prior mesoderm formation or to directly transdifferentiate fibroblast and adipose-derived stem cells [65-67]. These findings indicate that these molecules can boost the myogenic potential of several sorts of stem cells in order to increase their in vivo efficacy.However, it should be noted that in adult stem cells, the effect of HDACi is stage-specific. Iezzi et al. showed that when $\mathrm{C} 2 \mathrm{C} 12$ myoblasts are exposed to an HDACi prior to differentiation, the amount of myotube formation increases. In contrast, $\mathrm{C} 2 \mathrm{C} 12 \mathrm{~s}$ differentiated together with an $\mathrm{HDACi}$, lead to a decreased myotube formation [68]. These findings explain why some studies found a detrimental effect of HDACi on the myogenic differentiation $[69,70]$.

Instead of promoting acetylation, the same effect can be reached by demethylating the DNA. Interestingly, the modulation of methylation via prolonged treatment with 5-azacytidine, an inhibitor of DNA methylation, has been associated with an increased myogenic commitment of fibroblasts, mature adipocyte-derived dedifferentiated fat cells and cardiac cells [71-74]. Furthermore, in C2C12s, the treatment with 5-azacytidine resulted in enhanced expression of muscle-specific genes (including myogenin), increased myotube maturation and spontaneous contraction, suggesting that inhibition of methylation could be a suitable tool to further boost myogenic differentiation in already committed precursors $[75,76]$. However, in more immature stem cells, such as embryonic stem cells or mesenchymal stem cells, DNA demethylation seems to favour differentiation towards the cardiac lineage [77-79].

\subsection{2. miRNA Modulations}

Given their driving role in post-transcriptional gene regulation, miRNAs can contribute to epigenetic signalling and participate in the control of cell fate decisions. Moreover, their application potential is appealing thanks to their intrinsic properties to modulate several targets at once. In this view, manipulation of miRNAs to boost stem cells differentiation has been investigated. The traditional myomiRs have all been implicated in the enhancement of myoblasts differentiation. Studies have reported that the overexpression of miR-1 and miR133 enhances myogenic differentiation of murine SCs [64]. At the same time, the pivotal role of miR-206 in skeletal muscle regenerative strategies has been confirmed by in vitro studies on $\mathrm{C} 2 \mathrm{C} 12 \mathrm{~s}$ and in vivo studies on an animal model of skeletal muscle degeneration [80]. Furthermore, the implementation of miRNAs in stem cell differentiation has been reported for cardiac regeneration as well. Here myomiRs, together with a cardiac-specific miRNA, miR-208, have been used to directly reprogram cardiac fibroblasts to cells with cardiomyocytes-like properties, pointing at the synergistic effect of multiple miRNAs in driving stem cell fate [81].

More recent work has shown evidence for the use of miRNA mimics or antagomiRs (or anti-miRs, chemically engineered oligonucleotides that prevent miRNA binding) to enhance differentiation efficacy in iPSCs by directly targeting gene expression. Inhibition of miR121 and miR122, using antagomiRs, has resulted in increased differentiation of human iPSCs to hematopoietic lineages by acting on the stem cell factor (SCF)/c-KIT signalling pathway [82]. In other studies, researchers have shown that miRNAs can be employed to modulate maturation of human iPSCs derived cardiomyocytes. A study conducted on iPSC differentiation has reported that members of the miR-290 cluster (miR-291-3p, miR-294, and miR-295) are directly involved in murine iPSC reprogramming, and additionally can influence cardiomyogenic lineages maturation [83]. Interestingly, this study pointed to an additional role of 
miRNAs, not only in downstream lineage differentiation but also upstream, at the reprogramming stage. miRNAs are, in fact, intrinsically programmed to play a role in crucial aspects of reprogramming, as for example, chromatic remodelling, achieved through the targeting of HDAC and DNA demethylation [84]. Finally, another study has reported the use of miRNAs derived from mesenchymal stem cells to help the maturation of iPSCs derived cardiomyocytes [85].

With regards to skeletal muscle differentiation, miRNAs can be involved in the specification of fibre types when iPSCs are differentiated to myogenic lineages [86]. The synergistic effect of miRNAs has been employed to drive the myogenic commitment of human iPSC-derived progenitors, strengthening the potential application of miRNAs in guiding lineage fate decisions [87]. In recent years, a study has again reported a role for miRNAs in refining reprogramming of somatic cells to iPSCs: selectively blocking age-induced miR-195 resulted in efficient iPSC generation from elderly donor subject [88]. These last two studies highlight the role of miRNAs in rescuing a gap when generating iPSCs progenitors that is dependent on the somatic cell source, further positioning miRNAs in the whereabouts of stem cell fate decision processes.

\section{Genetics}

Not only on an epigenetic level but also genetically, advances have been made that could aid the future of stem cell therapy. Engineering of the human genome consists of insertion, deletion, modification and/or replacement of pieces of DNA. Advances in the genome-editing technologies allow us to gain precise control over the target site [89].

The first approach to manipulate the genome was through random insertions by viral vectors or plasmids [90]. However, this random integration can lead to disruption of the physiological gene expression-a phenomenon called insertional mutagenesis. When the mutagenesis disrupts a tumour suppressor gene or activates an oncogene, it can lead to the development of cancer [91,92]. The most well-known example is the clinical trial where gene therapy in patients with X-linked severe combined immunodeficiency led to the development of leukaemia in multiple cases [93].

To overcome this risk, later genome-engineering techniques use programmable endonucleases to induce double-stranded breaks in a targeted manner. These breaks will activate DNA repair mechanisms such as non-homologous end-joining (NHEJ) or, when a template is provided, homology-directed repair (HDR) [89]. The most frequently used endonucleases are zinc-finger nucleases (ZFNs), transcription activator-like effector nucleases (TALENs) and the Clustered Regularly Interspaced Short Palindromic Repeats and CRISPR associated proteins (CRISPR/Cas) system [94,95]. Although their targeting efficiency is quite similar, nowadays the CRISPR system is the most broadly used as it has reduced cytotoxicity, a broader target range and is the easiest to assemble compared to the other methods $[95,96]$. Initially, the CRISPR-system was identified in numerous archaea and bacteria as part of the adaptive immune system. The CRISPR consist of two components: a single guide RNA and a non-specific CRISPR-associated endonuclease (Cas). The Cas protein will cleave the DNA when the guide RNA binds to a specific region in the DNA that is flanked by a protospacer-adjacent motif (PAM) sequence. The most studied CRISPR is the type II CRISPR/Cas9, originating from the Streptococcus Pyogenes. With this system, the Cas9 endonucleases can be directed towards a specific genomic locus through a single guide RNA sequence followed by the canonical PAM sequence $5^{\prime}$-NGG-3' or 5'-NAG-3' $[97,98]$.

As MDs are mostly caused by a single gene mutation, genome engineering can be applied with the goal to restore certain genes that are affected. This would make it possible to derive stem cells from the patients themselves, thereby avoiding an immune response. Furthermore, genes that can help to control the cell fate or allow stem cell monitoring, can be inserted in a targeted manner. Here, we will discuss the most used option in which genome-engineering can be applied. 


\subsection{Correction of the Disease-Causing Mutation}

Risk of immune rejection is a major hurdle that heterologous stem cell therapy is facing. This issue can be overcome by using the patients' own cells. However, in order to use patient-specific cells, the underlying mutation needs to be corrected.

So far, most corrections have been performed on cells from patients with DMD (Table 1). DMD can be caused by deletions $(\sim 68 \%)$, duplications $(\sim 11 \%)$ or point mutations $(\sim 20 \%)$ in the dystrophin gene. Although these mutations can occur in the entire gene, some mutational "hotspots" are located between exons 2-19 and exons 45-55 [99]. When this mutation does not disrupt the reading frame, it results in a shorter but still functional protein, leading to a milder phenotype known as Becker MD. However, if the reading frame is disrupted or a premature stop codon is generated, the dystrophin will be completely absent, resulting in DMD [100] (Figure 3).

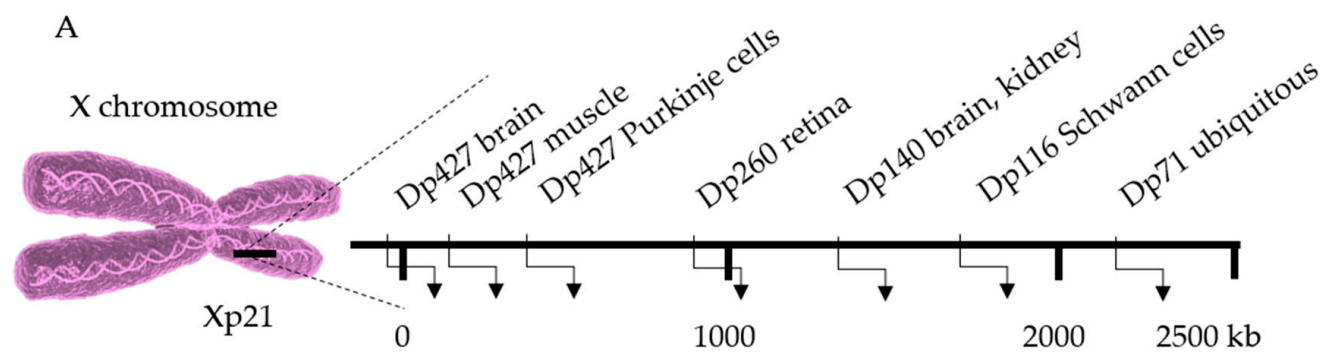

B

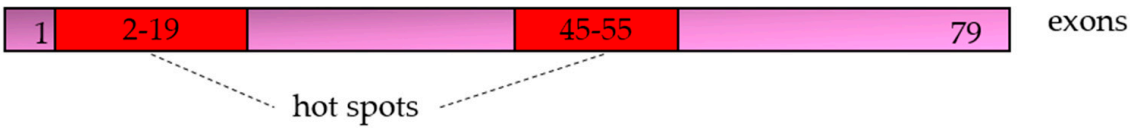

C

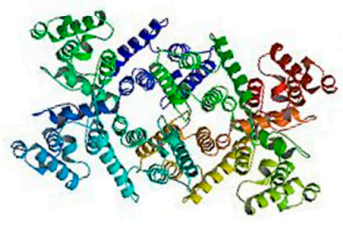

Full length dystrophin protein $(427 \mathrm{kDa})$

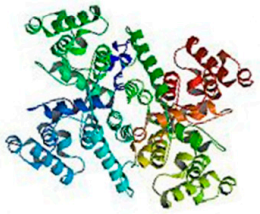

Altered dystrophin protein in BMD

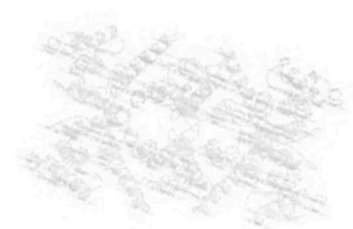

Absence of dystrophin protein in DMD

Figure 3. The dystrophin gene and its disease causing mutations. The dystrophin gene is located at chromosome Xp21 and presents several cell-specific promoters (A). The gene consists of 79 exons, distributed over about 2.5 million bases. In patients with Duchenne muscular dystrophy (DMD), protein translation is stopped prematurely due to the introduction of a stop codon or a frame-shift mutation. The major DMD deletion hot spots (in red) are located between exons 2-19 and between exons $45-55$. Deletions are found in about $60-65 \%$ of patients, and the frequency of duplications may range from $5 \%$ to $15 \%$. The remaining cases are caused by point mutations, intronic deletions, or exonic insertion of repetitive sequences (B). The full length dystrophin protein (427 kDA) contains an amino-terminal, a spectrin-like, a cysteine rich, and carboxy-terminal domains. In patients with Becker muscular dystrophy (BMD), mutations maintain the translational reading frame, generating a shorter but still functional dystrophin (C).

The dystrophin gene is the largest gene in the human genome, spanning more than 2.5 million base pairs [101] (Figure 3A). The large size of the gene renders it impossible to insert the complete gene into the genome. Alternative strategies include the use of truncated versions or dystrophin analogues. However, these additions can restore the function of dystrophin only partially [102-104]. Therefore, correction of the mutated gene can offer a solution. 
In general, there are four different strategies that can be used to correct the DMD mutation, depending on the type of mutation and its location [105] (Table 1). The most traditional strategy to restore the reading frame is by an in-frame deletion of one or more exons [106-108]. Instead of completely deleting an exon, the splice donor or acceptor sequence can be removed, leading to permanent exon skipping [106,109-112]. However, unless an exon duplication has occurred, both these strategies will produce a truncated version of the protein, leading to Becker MD (Figure 3C). In order to minimise the length of the genomic deletion, a double-stranded break can be created by NHEJ in order to restore the reading frame $[111,113,114]$. However, this strategy is only successful in some cases as only one-third of the deletions created by NHEJ are in-frame. Lastly, the DMD mutation can also be corrected by the knock-in of an exon which will lead to the expression of the full-length dystrophin [111,115].

It should be noted that the site-specific correction of the DMD mutation has not only been attempted in stem cells ex vivo but also directly in vivo [116,117]. This strategy has led to the successful restoration of dystrophin in both skeletal muscle and the heart of $m d x$ mice, a mouse model of DMD, and the canine model for DMD [109,110,118-120]. Although successful, there are still issues that remain to be tackled such as immunogenicity towards the delivery method and genotoxicity. Furthermore, this strategy requires the injection of the endonucleases directly into the patient, making it impossible to control for any off-target effects [121]. This can be overcome by correcting the mutation ex vivo in the patients' stem cells, making it possible to check for any off-target effect before re-injecting them.

Table 1. Ex vivo strategies for correction of mutations in the dystrophin gene.

\begin{tabular}{|c|c|c|c|c|c|}
\hline Technique & Cell Type & Mutation & Correction Strategy & Delivery Method & Reference \\
\hline Meganucleases & Myoblasts & $\Delta \mathrm{Ex} 45-52$ & Knock-in Ex45-52 & lentiviral & [115] \\
\hline ZFN & Myoblasts & $\Delta \mathrm{E} \times 48-50$ & Skip Ex51 & Electroporation & [107] \\
\hline \multirow[t]{2}{*}{ TALEN } & Myoblasts & $\Delta \mathrm{Ex} 45-52$ & $\Delta \mathrm{Ex} 44-54$ & Adenoviral & {$[122,123]$} \\
\hline & iPSC & $\Delta \operatorname{Ex} 44$ & $\begin{array}{l}\text { Knock-in Ex44 } \\
\text { Skip Ex44-45 } \\
\Delta \text { Ex53 }\end{array}$ & Electroporation & [111] \\
\hline \multirow[t]{8}{*}{ CRISPR/Cas9 } & Myoblasts & $\Delta \mathrm{Ex} 45-52$ & $\begin{array}{c}\Delta \mathrm{Ex} 44-54 \\
\Delta \mathrm{E} \times 51\end{array}$ & Adenoviral & {$[122,123]$} \\
\hline & Myoblasts & $\Delta \mathrm{Ex} 45-52$ & Frameshift Ex51 & Adenoviral & {$[122,123]$} \\
\hline & Myoblasts & Dupl. Ex2 & $\Delta$ DuplEx2 & Lentiviral & [124] \\
\hline & Myoblasts & $\Delta \mathrm{Ex} 51-53$ & $\begin{array}{c}\text { Reframing Ex50 and } \\
\text { Ex54 }\end{array}$ & Lipofectamine & [114] \\
\hline & iPSC & $\Delta \mathrm{Ex} 44$ & $\begin{array}{l}\text { Knock-in Ex44 } \\
\text { Skip Ex44-45 } \\
\text { Frameshift Ex44 }\end{array}$ & Electroporation & [111] \\
\hline & iPSC & $\begin{array}{c}\Delta 48-50 \\
\text { Dupl. Ex55-59 } \\
\text { Pt Ex47 }\end{array}$ & $\begin{array}{c}\text { Skip Ex47-52 } \\
\Delta \text { DuplEx55-59 } \\
\Delta \text { mutated Ex47 }\end{array}$ & Lipofectamine & [112] \\
\hline & iPSCs & $\Delta$ Ex8-9 & $\begin{array}{c}\Delta \mathrm{E} \times 3-9, \Delta \mathrm{Ex} 6-9, \text { or } \\
\Delta \operatorname{Ex}-11\end{array}$ & Electroporation & [108] \\
\hline & iPSC & $\begin{array}{c}\text { Dup. Ex50 } \\
\Delta \text { Ex46-51 } \\
\Delta \text { Ex46-47 }\end{array}$ & $\Delta \mathrm{Ex} 45-55$ & Electroporation & [113] \\
\hline CRISPR-Cpf1 & iPSC & $\Delta \mathrm{Ex} 48-59$ & Skip Ex51 & Electroporation & [125] \\
\hline
\end{tabular}

ZFN: Zinc-Finger Nucleases; TALEN: Transcription Activator-Like Effector Nucleases; CRISPR: Clustered Regularly Interspaced Short Palindromic Repeats; Cas: CRISPR-associated Protein; Cpf: CRISPR from Prevotella and Francisella 1; $\Delta$ : Deletion; Ex: Exon; Dupl: Duplication; Pt: Point mutation.

The earliest attempts to restore the dystrophin gene ex vivo focussed on myoblasts, using either mega-nucleases, ZFNs or TALENs [107,115,122,123]. Although all strategies successfully restored dystrophin expression, only the myoblasts corrected with ZFNs were tested in vivo for their ability to restore the skeletal muscle [107]. Afterwards, all additional attempts used the CRISPR-Cas9 system to correct the DMD mutation in myoblasts [106,114,122,123,125]. A direct comparison between the CRISPR/Cas9 and TALEN by Maggio et al. showed that the CRISPR/Cas9 offers the highest targeting flexibility and the least off-target effects [122,123]. 
Later attempts to correct the DMD mutation were focused mainly on PSCs and their derivatives due to their self-renewal abilities, which allow long-term in vitro manipulation [126]. The first correction of the dystrophin in patient-iPSCs was reported in 2015, using the TALENs to guide homologous repair [111]. In this study, the TALEN approach was compared directly to the CRISPR-Cas9 system. Although both systems were able to restore the dystrophin expression, the CRISPR-Cas9 system has been associated with less off-target sites [111]. A similar direct comparison of the two techniques showed a better gene-editing efficiency of the CRISPR-Cas9 system compared to TALENs [127]. Unsurprisingly, all published attempts in PSCs used the CRISPR-Cas9 system to restore the dystrophin gene $[108,122,123]$.

In order to avoid the need for a new CRISPR/Cas9 complex for each patient, some groups came with a strategy to correct a diversity of DMD mutations with a single CRISPR. By deleting a large fragment within a mutational hotspot, dystrophin expression can be restored for around $60 \%$ of the DMD patients $[112,113]$. All patient-derived iPSCs showed a morphological and functional improvement after correction, when differentiated towards both skeletal muscle and cardiomyocytes [108,111-113]. Although the CRISPR-Cas9 system is the most effective technique so far, other techniques are being optimised. An example recently tested in DMD, is the CRISPR from Prevotella and Francisella 1 (CRISPR-Cpf1), a CRISPR system that shows greater flexibility in target sites and higher activation of the DNA repair mechanisms, thereby enhancing the efficiency [124]. Lastly, although most studies focus on DMD, the same gene-editing strategies efficiently correct the disease-causing mutation in other MDs, such as Limb-girlde MD type 2D and myotonic dystrophy [128,129].

\subsection{Gene Addition}

Besides the integration of the healthy gene within a certain disease, much attention is paid to the insertion of genes that can help to gain more insight and control over the stem cells and their fate. In order to avoid insertional mutagenesis, the gene integration can be targeted towards so-called safe-harbour loci. Genomic safe-harbours are regions in the genome that ensure stable expression of the transgene without the risk of interrupting the endogenous gene expression [130]. The most well-known safe-harbour loci in the genome are the adeno-associated virus integration-site 1 (AAVS1) and the C-C motif chemokine receptor 5 (CCR5) [131,132].

\subsubsection{Transcription Factors}

One of the most used examples is the integration of transcription factors to improve skeletal muscle differentiation in pluripotent stem cells [133]. Over the years, the integration of key regulators of skeletal myogenesis, such as Pax7 and MyoD, has led to a reproducible and highly efficient in vitro differentiation [134-137]. As most of these transcription factors only need to be active temporarily, the Piggy-Bac transposase system has gained much interest. This system links the transcription factors to a transposon making the construct removable upon administration of a transposase. Excision of this system leaves no trace, avoiding the risk for insertional mutagenesis [138].

\subsubsection{Reporter Genes}

Reporter genes encode for proteins that have a high affinity for a certain probe. Once delivered in vivo, the cells can be visualised upon administration of the matching probe, thereby allowing longitudinal monitoring of the cell survival $[139,140]$. In the field of MD, reporter genes are widely used on a preclinical level. Green fluorescent protein for immunofluorescence and luciferase for bioluminescence imaging are the most widely used [141-143]. However, recently, attempts have been made to integrate reporter genes compatible with imaging modalities that can be applied clinically such as positron emission tomography (PET) and single-photon emission computed tomography (SPECT) [142,144]. In order to move this application towards the clinic, site-specific integration is essential. So far, only one report shows the integration of these reporter genes in a site-specific manner [144]. More specifically, Holvoet et al. integrated the human sodium iodide symporter into 
the AAVS1 locus of embryonic stem cells through the use of ZFNs. This integration led to a stable expression of the reporter over time without influencing the functionality and differentiation potential of the cells. By combining targeted genome-engineering with stem cell imaging, the transition of stem cell therapy to a clinical setting will be greatly accelerated.

\subsubsection{Suicide Genes}

The integration of suicide genes is of great importance when using PSCs, as differentiations are often impure leading to the risk for teratoma formation [145]. Suicide genes are used as safety switches in order to intervene when PSC-derivatives undergo excessive proliferation. So far, this system has been mostly investigated on a PSC-level, making its use to specifically eliminate cells from the skeletal and cardiac muscle less explored. The first suicide gene used in the area of MD, is the inducible Caspase 9 system, an enzyme that induces apoptosis upon administration of a chemical inducer of dimerisation. This system was used eight weeks after injection of mesodermal progenitors into the skeletal muscle, showing complete clearance of the injected stem cells [146]. Within the cardiac muscle, the human somatostatin receptor 2 was incorporated, which made it possible to eliminate the engrafted cells upon the administration of ${ }^{177} \mathrm{Lu}$-DOTATATE, a $\beta^{-}$-emitting radioisotope specifically binding the integrated receptor. The benefit of this gene is that, just by adding a different radionuclide, it can also serve as a reporter gene. This means that by integrating a single gene, the injected stem cells can be monitored and, upon observation of an abnormal growth, can be eliminated [147].

\section{Conclusions and Future Directions}

We examined the convergence of genetics and epigenetics that act in concert to advance our knowledge on myogenic stem cells and accelerate the development of novel therapies. We provided an overview of the genetic and epigenetic advances that can result in novel therapeutic treatments for muscle disorders. Adult stem cells, including SCs and MABs can transfer some epigenetic marks to their differentiated counterparts but are extremely rare in skeletal muscles. On the other hand, it is known that during reprogramming, iPS cells retain some epigenetic memory from somatic sources and these epigenetic markers affect cell-based therapies. At the moment, we are facing technical challenges, including the possibility to generate fully mature somatic cells from iPS cells, routine methods to carry out epigenomic analyses from a single cell and precise computational procedures to handle big data. Thus, a better knowledge of the interplay among genetic and epigenetic factors combined with single cell analysis in order to improve stem cell-based therapies is mandatory. In this view, more and more therapeutic approaches using miRNA mimics or antagomirs combined with gene-editing and iPS cell technology are expected in the near future.

Author Contributions: Conceptualization, N.B., G.G. and M.S.; writing-original draft preparation, N.B. and G.G.; writing-review and editing, N.B., G.G. and M.S.; visualization, N.B. and M.S.

Funding: This work was supported by “Opening the Future” campaign (EJJ-OPTFUT-02010), CARIPLO 2015_0634, FWO (G088715N, G060612N, G0A8813N), GOA (EJJC2161- GOA/11/012), IUAP-VII/07 (EJJ-C4851-17/07-P), OT 09-053 (EJJC0420-OT/09/053), Project Financing Stem Cells (PFO3 10/019) and RondouFonds voor Duchenne Onderzoek (EQQ-FODUCH-O2010). N.B. is a recipient of an FWO aspirant grant \#1S07917N.

Acknowledgments: We would like to thank Christophe Deroose, Bryan Holvoet and Domiziana Costamagna for their insights and suggestions.

Conflicts of Interest: The authors declare no conflict of interest. 


\section{Abbreviations}

\begin{tabular}{|c|c|}
\hline AAVS1 & Adeno-Associated Virus Integration-Site 1 \\
\hline Cas & CRISPR-Associated Protein \\
\hline CRISPR & Clustered Regularly Interspaced Short Palindromic Repeats \\
\hline DMD & Duchenne Muscular Dystrophy \\
\hline DNMT & DNA Methyltransferases \\
\hline HAT & Histone Acetyltransferases \\
\hline HDAC & Histone Deacetylases \\
\hline $\mathrm{HDACi}$ & Histone Deacetylase inhibitors \\
\hline HDR & Homology-Directed Repair \\
\hline HMT & Histone Methyltransferases \\
\hline iPSCs & Induced Pluripotent Stem Cells \\
\hline MAB & Mesoangioblast \\
\hline MD & Muscular Dystrophy \\
\hline $\operatorname{miRNA}$ & MicroRNA \\
\hline MRF & Muscle Regulatory Factor \\
\hline Myf5 & Myogenic Factor 5 \\
\hline MyoD & Muscle Determining Factor \\
\hline NHEJ & Non-Homologous End-Joining \\
\hline PAM & Protospacer-Adjacent Motif \\
\hline PAX & Paired Box Gene \\
\hline SCs & Satellite Cells \\
\hline TALEN & Transcription Activator-Like Effector Nucleases \\
\hline ZFN & Zinc-Finger Nuclease \\
\hline
\end{tabular}

\section{References}

1. Chal, J.; Pourquie, O. Making muscle: Skeletal myogenesis in vivo and in vitro. Development 2017, 144, 2104-2122. [CrossRef]

2. Bentzinger, C.F.; Wang, Y.X.; Rudnicki, M.A. Building muscle: Molecular regulation of myogenesis. Cold Spring Harb. Perspect. Biol. 2012, 4. [CrossRef]

3. Yokoyama, S.; Asahara, H. The myogenic transcriptional network. Cell Mol. Life Sci. 2011, 68, 1843-1849. [CrossRef]

4. Chen, J.C.J.; Goldhamer, D.J. Skeletal muscle stem cells. Reprod. Biol.Endocrin. 2003, 1, 101. [CrossRef] [PubMed]

5. Tedesco, F.S.; Dellavalle, A.; Diaz-Manera, J.; Messina, G.; Cossu, G. Repairing skeletal muscle: Regenerative potential of skeletal muscle stem cells. J. Clin. Investig. 2010, 120, 11-19. [CrossRef] [PubMed]

6. Quattrocelli, M.; Cassano, M.; Crippa, S.; Perini, I.; Sampaolesi, M. Cell therapy strategies and improvements for muscular dystrophy. Cell Death Differ. 2010, 17, 1222-1229. [CrossRef] [PubMed]

7. Straub, V.; Campbell, K.P. Muscular dystrophies and the dystrophin-glycoprotein complex. Curr. Opin. Neurol. 1997, 10, 168-175. [CrossRef]

8. Mercuri, E.; Muntoni, F. Muscular dystrophies. Lancet 2013, 381, 845-860. [CrossRef]

9. Birnkrant, D.J.; Bushby, K.; Bann, C.M.; Apkon, S.D.; Blackwell, A.; Colvin, M.K.; Cripe, L.; Herron, A.R.; Kennedy, A.; Kinnett, K.; et al. Diagnosis and management of duchenne muscular dystrophy, part 3: Primary care, emergency management, psychosocial care, and transitions of care across the lifespan. Lancet Neurol. 2018, 17, 445-455. [CrossRef]

10. Fan, Y.; Maley, M.; Beilharz, M.; Grounds, M. Rapid death of injected myoblasts in myoblast transfer therapy. Muscle Nerve. 1996, 19, 853-860. [CrossRef]

11. Skuk, D.; Goulet, M.; Tremblay, J.P. Use of repeating dispensers to increase the efficiency of the intramuscular myogenic cell injection procedure. Cell Transplant. 2006, 15, 659-663. [CrossRef] [PubMed]

12. Dellavalle, A.; Sampaolesi, M.; Tonlorenzi, R.; Tagliafico, E.; Sacchetti, B.; Perani, L.; Innocenzi, A.; Galvez, B.G.; Messina, G.; Morosetti, R.; et al. Pericytes of human skeletal muscle are myogenic precursors distinct from satellite cells. Nat. Cell. Biol. 2007, 9, 255-267. [CrossRef] 
13. Cossu, G.; Previtali, S.C.; Napolitano, S.; Cicalese, M.P.; Tedesco, F.S.; Nicastro, F.; Noviello, M.; Roostalu, U.; Natali Sora, M.G.; Scarlato, M.; et al. Intra-arterial transplantation of hla-matched donor mesoangioblasts in duchenne muscular dystrophy. EMBO Mol. Med. 2015, 7, 1513-1528. [CrossRef] [PubMed]

14. Sampaolesi, M.; Torrente, Y.; Innocenzi, A.; Tonlorenzi, R.; D’Antona, G.; Pellegrino, M.A.; Barresi, R.; Bresolin, N.; De Angelis, M.G.; Campbell, K.P.; et al. Cell therapy of alpha-sarcoglycan null dystrophic mice through intra-arterial delivery of mesoangioblasts. Science 2003, 301, 487-492. [CrossRef]

15. Sampaolesi, M.; Blot, S.; D'Antona, G.; Granger, N.; Tonlorenzi, R.; Innocenzi, A.; Mognol, P.; Thibaud, J.L.; Galvez, B.G.; Barthelemy, I.; et al. Mesoangioblast stem cells ameliorate muscle function in dystrophic dogs. Nature 2006, 444, 574-579. [CrossRef]

16. Barreiro, E.; Tajbakhsh, S. Epigenetic regulation of muscle development. J. Muscle Res. Cell Motil. 2017, 38, 31-35. [CrossRef]

17. Robinson, D.C.L.; Dilworth, F.J. Epigenetic regulation of adult myogenesis. Curr. Top. Dev. Biol. 2018, 126, 235-284. [PubMed]

18. Smith, Z.D.; Meissner, A. DNA methylation: Roles in mammalian development. Nat. Rev. Genet. 2013, 14, 204-220. [CrossRef]

19. Aguirre-Arteta, A.M.; Grunewald, I.; Cardoso, M.C.; Leonhardt, H. Expression of an alternative dnmt1 isoform during muscle differentiation. Cell Growth Differ. 2000, 11, 551-559.

20. Carrio, E.; Diez-Villanueva, A.; Lois, S.; Mallona, I.; Cases, I.; Forn, M.; Peinado, M.A.; Suelves, M. Deconstruction of DNA methylation patterns during myogenesis reveals specific epigenetic events in the establishment of the skeletal muscle lineage. Stem Cells 2015, 33, 2025-2036. [CrossRef]

21. Liu, Y.; Sun, L.; Jost, J.P. In differentiating mouse myoblasts DNA methyltransferase is posttranscriptionally and posttranslationally regulated. Nucleic Acids Res. 1996, 24, 2718-2722. [CrossRef]

22. Black, J.C.; Van Rechem, C.; Whetstine, J.R. Histone lysine methylation dynamics: Establishment, regulation, and biological impact. Mol. Cell 2012, 48, 491-507. [CrossRef]

23. Mozzetta, C.; Consalvi, S.; Saccone, V.; Forcales, S.V.; Puri, P.L.; Palacios, D. Selective control of pax7 expression by tnf-activated p38alpha/polycomb repressive complex 2 (prc2) signaling during muscle satellite cell differentiation. Cell Cycle 2011, 10, 191-198. [CrossRef]

24. Palacios, D.; Mozzetta, C.; Consalvi, S.; Caretti, G.; Saccone, V.; Proserpio, V.; Marquez, V.E.; Valente, S.; Mai, A.; Forcales, S.V.; et al. Tnf/p38alpha/polycomb signaling to pax7 locus in satellite cells links inflammation to the epigenetic control of muscle regeneration. Cell Stem Cell 2010, 7, 455-469. [CrossRef]

25. Stojic, L.; Jasencakova, Z.; Prezioso, C.; Stützer, A.; Bodega, B.; Pasini, D.; Klingberg, R.; Mozzetta, C.; Margueron, R.; Puri, P.L.; et al. Chromatin regulated interchange between polycomb repressive complex 2 (prc2)-ezh2 and prc2-ezh1 complexes controls myogenin activation in skeletal muscle cells. Epigenetics Chromatin 2011, 4, 16. [CrossRef] [PubMed]

26. Jin, W.; Peng, J.; Jiang, S. The epigenetic regulation of embryonic myogenesis and adult muscle regeneration by histone methylation modification. Biochem. Biophys. Rep. 2016, 6, 209-219. [CrossRef] [PubMed]

27. Moresi, V.; Marroncelli, N.; Adamo, S. New insights into the epigenetic control of satellite cells. World J. Stem Cells 2015, 7, 945-955. [CrossRef] [PubMed]

28. Asp, P.; Blum, R.; Vethantham, V.; Parisi, F.; Micsinai, M.; Cheng, J.; Bowman, C.; Kluger, Y.; Dynlacht, B.D. Genome-wide remodeling of the epigenetic landscape during myogenic differentiation. Proc. Natl. Acad. Sci. USA 2011, 108, E149-E158. [CrossRef] [PubMed]

29. Cui, H.; Bansal, V.; Grunert, M.; Malecova, B.; Dall'Agnese, A.; Latella, L.; Gatto, S.; Ryan, T.; Schulz, K.; Chen, W.; et al. Muscle-relevant genes marked by stable h3k4me2/3 profiles and enriched myod binding during myogenic differentiation. PLoS ONE 2017, 12, e0179464. [CrossRef]

30. Lilja, K.C.; Zhang, N.; Magli, A.; Gunduz, V.; Bowman, C.J.; Arpke, R.W.; Darabi, R.; Kyba, M.; Perlingeiro, R.; Dynlacht, B.D. Pax7 remodels the chromatin landscape in skeletal muscle stem cells. PLoS ONE 2017, 12, e0176190. [CrossRef]

31. Wang, J.; Abate-Shen, C. The msx1 homeoprotein recruits g9a methyltransferase to repressed target genes in myoblast cells. PLoS ONE 2012, 7, e37647. [CrossRef] [PubMed]

32. Zhang, R.H.; Judson, R.N.; Liu, D.Y.; Kast, J.; Rossi, F.M. The lysine methyltransferase ehmt2/g9a is dispensable for skeletal muscle development and regeneration. Skelet Muscle 2016, 6, 22. [CrossRef]

33. Mal, A.K. Histone methyltransferase suv39h1 represses myod-stimulated myogenic differentiation. EMBO J. 2006, 25, 3323-3334. [CrossRef] [PubMed] 
34. Chatterjee, B.; Wolff, D.W.; Jothi, M.; Mal, M.; Mal, A.K. P38alpha mapk disables kmt1a-mediated repression of myogenic differentiation program. Skelet Muscle 2016, 6, 28. [CrossRef] [PubMed]

35. Ling, B.M.; Bharathy, N.; Chung, T.K.; Kok, W.K.; Li, S.; Tan, Y.H.; Rao, V.K.; Gopinadhan, S.; Sartorelli, V.; Walsh, M.J.; et al. Lysine methyltransferase g9a methylates the transcription factor myod and regulates skeletal muscle differentiation. Proc. Natl. Acad. Sci. USA 2012, 109, 841-846. [CrossRef]

36. De la Serna, I.L.; Carlson, K.A.; Imbalzano, A.N. Mammalian swi/snf complexes promote myod-mediated muscle differentiation. Nat. Genet. 2001, 27, 187-190. [CrossRef] [PubMed]

37. Forcales, S.V.; Albini, S.; Giordani, L.; Malecova, B.; Cignolo, L.; Chernov, A.; Coutinho, P.; Saccone, V.; Consalvi, S.; Williams, R.; et al. Signal-dependent incorporation of myod-baf60c into brg1-based swi/snf chromatin-remodelling complex. EMBO J. 2012, 31, 301-316. [CrossRef] [PubMed]

38. Tao, Y.; Neppl, R.L.; Huang, Z.P.; Chen, J.; Tang, R.H.; Cao, R.; Zhang, Y.; Jin, S.W.; Wang, D.Z. The histone methyltransferase set7/9 promotes myoblast differentiation and myofibril assembly. J. Cell Biol. 2011, 194, 551-565. [CrossRef] [PubMed]

39. Verrier, L.; Escaffit, F.; Chailleux, C.; Trouche, D.; Vandromme, M. A new isoform of the histone demethylase jmjd2a/kdm4a is required for skeletal muscle differentiation. PLoS Genet. 2011, 7, e1001390. [CrossRef] [PubMed]

40. Soleimani, V.D.; Yin, H.; Jahani-Asl, A.; Ming, H.; Kockx, C.E.; van Ijcken, W.F.; Grosveld, F.; Rudnicki, M.A. Snail regulates myod binding-site occupancy to direct enhancer switching and differentiation-specific transcription in myogenesis. Mol. Cell 2012, 47, 457-468. [CrossRef]

41. Cho, O.H.; Mallappa, C.; Hernández-Hernández, J.M.; Rivera-Pérez, J.A.; Imbalzano, A.N. Contrasting roles for myod in organizing myogenic promoter structures during embryonic skeletal muscle development. Dev. Dyn. 2015, 244, 43-55. [CrossRef]

42. Puri, P.L.; Iezzi, S.; Stiegler, P.; Chen, T.T.; Schiltz, R.L.; Muscat, G.E.; Giordano, A.; Kedes, L.; Wang, J.Y.; Sartorelli, V. Class i histone deacetylases sequentially interact with myod and prb during skeletal myogenesis. Mol. Cell 2001, 8, 885-897. [CrossRef]

43. Fauquier, L.; Azzag, K.; Parra, M.A.M.; Quillien, A.; Boulet, M.; Diouf, S.; Carnac, G.; Waltzer, L.; Gronemeyer, H.; Vandel, L. Cbp and p300 regulate distinct gene networks required for human primary myoblast differentiation and muscle integrity. Sci. Rep. 2018, 8, 12629. [CrossRef]

44. Sartorelli, V.; Puri, P.L.; Hamamori, Y.; Ogryzko, V.; Chung, G.; Nakatani, Y.; Wang, J.Y.; Kedes, L. Acetylation of myod directed by pcaf is necessary for the execution of the muscle program. Mol. Cell 1999, 4, 725-734. [CrossRef]

45. Ha, M.; Kim, V.N. Regulation of microrna biogenesis. Nat. Rev. Mol. Cell Biol. 2014, 15, 509-524. [CrossRef] [PubMed]

46. Yao, Q.; Chen, Y.; Zhou, X. The roles of micrornas in epigenetic regulation. Curr. Opin. Chem. Biol. 2019, 51, 11-17. [CrossRef] [PubMed]

47. Xie, H.F.; Liu, Y.Z.; Du, R.; Wang, B.; Chen, M.T.; Zhang, Y.Y.; Deng, Z.L.; Li, J. Mir-377 induces senescence in human skin fibroblasts by targeting DNA methyltransferase 1. Cell Death Dis. 2017, 8, e2663. [CrossRef] [PubMed]

48. Wang, L.; Yao, J.; Sun, H.; He, K.; Tong, D.; Song, T.; Huang, C. Microrna-101 suppresses progression of lung cancer through the pten/akt signaling pathway by targeting DNA methyltransferase 3a. Oncol. Lett. 2017, 13, 329-338. [CrossRef]

49. Song, J.; Jin, E.H.; Kim, D.; Kim, K.Y.; Chun, C.H.; Jin, E.J. Microrna-222 regulates mmp-13 via targeting hdac-4 during osteoarthritis pathogenesis. BBA Clin. 2015, 3, 79-89. [CrossRef]

50. Quattrocelli, M.; Sampaolesi, M. The mesmirizing complexity of micrornas for striated muscle tissue engineering. Adv. Drug. Deliv. Rev. 2015, 88, 37-52. [CrossRef]

51. Chen, J.F.; Mandel, E.M.; Thomson, J.M.; Wu, Q.; Callis, T.E.; Hammond, S.M.; Conlon, F.L.; Wang, D.Z. The role of microrna-1 and microrna-133 in skeletal muscle proliferation and differentiation. Nat. Genet. 2006, 38, 228-233. [CrossRef] [PubMed]

52. Kim, H.K.; Lee, Y.S.; Sivaprasad, U.; Malhotra, A.; Dutta, A. Muscle-specific microrna mir-206 promotes muscle differentiation. J. Cell Biol. 2006, 174, 677-687. [CrossRef]

53. Naguibneva, I.; Ameyar-Zazoua, M.; Polesskaya, A.; Ait-Si-Ali, S.; Groisman, R.; Souidi, M.; Cuvellier, S.; Harel-Bellan, A. The microrna mir-181 targets the homeobox protein hox-a11 during mammalian myoblast differentiation. Nat. Cell Biol. 2006, 8, 278-284. [CrossRef] [PubMed] 
54. Sun, Q.; Zhang, Y.; Yang, G.; Chen, X.; Zhang, Y.; Cao, G.; Wang, J.; Sun, Y.; Zhang, P.; Fan, M.; et al. Transforming growth factor-beta-regulated mir-24 promotes skeletal muscle differentiation. Nucleic Acids Res. 2008, 36, 2690-2699. [CrossRef] [PubMed]

55. Crist, C.G.; Montarras, D.; Pallafacchina, G.; Rocancourt, D.; Cumano, A.; Conway, S.J.; Buckingham, M. Muscle stem cell behavior is modified by microrna-27 regulation of pax3 expression. Proc. Natl. Acad. Sci. USA 2009, 106, 13383-13387. [CrossRef] [PubMed]

56. Crippa, S.; Cassano, M.; Messina, G.; Galli, D.; Galvez, B.G.; Curk, T.; Altomare, C.; Ronzoni, F.; Toelen, J.; Gijsbers, R.; et al. Mir669a and mir669q prevent skeletal muscle differentiation in postnatal cardiac progenitors. J. Cell Biol. 2011, 193, 1197-1212. [CrossRef] [PubMed]

57. Quattrocelli, M.; Crippa, S.; Montecchiani, C.; Camps, J.; Cornaglia, A.I.; Boldrin, L.; Morgan, J.; Calligaro, A.; Casasco, A.; Orlacchio, A.; et al. Long-term mir-669a therapy alleviates chronic dilated cardiomyopathy in dystrophic mice. J. Am. Heart Assoc. 2013, 2, e000284. [CrossRef] [PubMed]

58. Consalvi, S.; Sandona, M.; Saccone, V. Epigenetic reprogramming of muscle progenitors: Inspiration for clinical therapies. Stem Cells Int. 2016, 2016, 6093601. [CrossRef]

59. Consalvi, S.; Mozzetta, C.; Bettica, P.; Germani, M.; Fiorentini, F.; Del Bene, F.; Rocchetti, M.; Leoni, F.; Monzani, V.; Mascagni, P.; et al. Preclinical studies in the mdx mouse model of duchenne muscular dystrophy with the histone deacetylase inhibitor givinostat. Mol. Med 2013, 19, 79-87. [CrossRef] [PubMed]

60. Minetti, G.C.; Colussi, C.; Adami, R.; Serra, C.; Mozzetta, C.; Parente, V.; Fortuni, S.; Straino, S.; Sampaolesi, M.; Di Padova, M.; et al. Functional and morphological recovery of dystrophic muscles in mice treated with deacetylase inhibitors. Nat. Med. 2006, 12, 1147-1150. [CrossRef]

61. Furlan, A.; Monzani, V.; Reznikov, L.L.; Leoni, F.; Fossati, G.; Modena, D.; Mascagni, P.; Dinarello, C.A. Pharmacokinetics, safety and inducible cytokine responses during a phase 1 trial of the oral histone deacetylase inhibitor itf2357 (givinostat). Mol. Med. 2011, 17, 353-362. [CrossRef]

62. Bettica, P.; Petrini, S.; D’Oria, V.; D’Amico, A.; Catteruccia, M.; Pane, M.; Sivo, S.; Magri, F.; Brajkovic, S.; Messina, S.; et al. Histological effects of givinostat in boys with duchenne muscular dystrophy. Neuromuscul Disord 2016, 26, 643-649. [CrossRef]

63. Iezzi, S.; Di Padova, M.; Serra, C.; Caretti, G.; Simone, C.; Maklan, E.; Minetti, G.; Zhao, P.; Hoffman, E.P.; Puri, P.L.; et al. Deacetylase inhibitors increase muscle cell size by promoting myoblast recruitment and fusion through induction of follistatin. Dev. Cell 2004, 6, 673-684. [CrossRef]

64. Saccone, V.; Consalvi, S.; Giordani, L.; Mozzetta, C.; Barozzi, I.; Sandoná, M.; Ryan, T.; Rojas-Muñoz, A.; Madaro, L.; Fasanaro, P.; et al. Hdac-regulated myomirs control baf60 variant exchange and direct the functional phenotype of fibro-adipogenic progenitors in dystrophic muscles. Genes. Dev. 2014, 28, 841-857. [CrossRef] [PubMed]

65. Albini, S.; Coutinho, P.; Malecova, B.; Giordani, L.; Savchenko, A.; Forcales, S.V.; Puri, P.L. Epigenetic reprogramming of human embryonic stem cells into skeletal muscle cells and generation of contractile myospheres. Cell Rep. 2013, 3, 661-670. [CrossRef] [PubMed]

66. Li, Q.; Foote, M.; Chen, J. Effects of histone deacetylase inhibitor valproic acid on skeletal myocyte development. Sci. Rep. 2014, 4, 7207. [CrossRef] [PubMed]

67. Bansal, V.; De, D.; An, J.; Kang, T.M.; Jeong, H.J.; Kang, J.S.; Kim, K.K. Chemical induced conversion of mouse fibroblasts and human adipose-derived stem cells into skeletal muscle-like cells. Biomaterials 2019, 193, 30-46. [CrossRef] [PubMed]

68. Iezzi, S.; Cossu, G.; Nervi, C.; Sartorelli, V.; Puri, P.L. Stage-specific modulation of skeletal myogenesis by inhibitors of nuclear deacetylases. Proc. Natl. Acad. Sci. USA 2002, 99, 7757-7762. [CrossRef]

69. Mal, A.; Sturniolo, M.; Schiltz, R.L.; Ghosh, M.K.; Harter, M.L. A role for histone deacetylase hdac1 in modulating the transcriptional activity of myod: Inhibition of the myogenic program. EMBO J. 2001, 20, 1739-1753. [CrossRef]

70. Johnston, L.A.; Tapscott, S.J.; Eisen, H. Sodium butyrate inhibits myogenesis by interfering with the transcriptional activation function of myod and myogenin. Mol. Cell Biol. 1992, 12, 5123-5130. [CrossRef]

71. Kazama, T.; Fujie, M.; Endo, T.; Kano, K. Mature adipocyte-derived dedifferentiated fat cells can transdifferentiate into skeletal myocytes in vitro. Biochem. Biophys. Res. Commun. 2008, 377, 780-785. [CrossRef] 
72. Kaur, K.; Yang, J.; Eisenberg, C.A.; Eisenberg, L.M. 5-azacytidine promotes the transdifferentiation of cardiac cells to skeletal myocytes. Cell. Reprogram. 2014, 16, 324-330. [CrossRef]

73. Taylor, S.M.; Jones, P.A. Multiple new phenotypes induced in 10t1/2 and 3t3 cells treated with 5-azacytidine. Cell 1979, 17, 771-779. [CrossRef]

74. Constantinides, P.G.; Jones, P.A.; Gevers, W. Functional striated muscle cells from non-myoblast precursors following 5-azacytidine treatment. Nature 1977, 267, 364-366. [CrossRef]

75. Senesi, P.; Luzi, L.; Montesano, A.; Terruzzi, I. DNA demethylation enhances myoblasts hypertrophy during the late phase of myogenesis activating the igf-i pathway. Endocrine 2014, 47, 244-254. [CrossRef] [PubMed]

76. Scarpa, S.; Lucarelli, M.; Palitti, F.; Carotti, D.; Strom, R. Simultaneous myogenin expression and overall DNA hypomethylation promote in vitro myoblast differentiation. Cell Growth Differ. 1996, 7, 1051-1058.

77. Choi, S.C.; Yoon, J.; Shim, W.J.; Ro, Y.M.; Lim, D.S. 5-azacytidine induces cardiac differentiation of p19 embryonic stem cells. Exp. Mol. Med. 2004, 36, 515-523. [CrossRef]

78. Qian, Q.; Qian, H.; Zhang, X.; Zhu, W.; Yan, Y.; Ye, S.; Peng, X.; Li, W.; Xu, Z.; Sun, L.; et al. 5-azacytidine induces cardiac differentiation of human umbilical cord-derived mesenchymal stem cells by activating extracellular regulated kinase. Stem Cells Dev. 2012, 21, 67-75. [CrossRef] [PubMed]

79. Wakitani, S.; Saito, T.; Caplan, A.I. Myogenic cells derived from rat bone marrow mesenchymal stem cells exposed to 5-azacytidine. Muscle Nerve. 1995, 18, 1417-1426. [CrossRef]

80. Liu, N.; Williams, A.H.; Maxeiner, J.M.; Bezprozvannaya, S.; Shelton, J.M.; Richardson, J.A.; Bassel-Duby, R.; Olson, E.N. Microrna-206 promotes skeletal muscle regeneration and delays progression of duchenne muscular dystrophy in mice. J. Clin. Investig. 2012, 122, 2054-2065. [CrossRef]

81. Jayawardena, T.M.; Egemnazarov, B.; Finch, E.A.; Zhang, L.; Payne, J.A.; Pandya, K.; Zhang, Z.; Rosenberg, P.; Mirotsou, M.; Dzau, V.J. Microrna-mediated in vitro and in vivo direct reprogramming of cardiac fibroblasts to cardiomyocytes. Circ. Res. 2012, 110, 1465-1473. [CrossRef]

82. Lee, J.Y.; Kim, M.; Heo, H.R.; Ha, K.S.; Han, E.T.; Park, W.S.; Yang, S.R.; Hong, S.H. Inhibition of microrna-221 and 222 enhances hematopoietic differentiation from human pluripotent stem cells via c-kit upregulation. Mol. Cells 2018, 41, 971-978. [PubMed]

83. Judson, R.L.; Babiarz, J.E.; Venere, M.; Blelloch, R. Embryonic stem cell-specific micrornas promote induced pluripotency. Nat. Biotechnol. 2009, 27, 459-461. [CrossRef]

84. Ying, S.Y.; Fang, W.; Lin, S.L. The mir-302-mediated induction of pluripotent stem cells (ipsc): Multiple synergistic reprogramming mechanisms. Methods Mol. Biol. 2018, 1733, 283-304.

85. Yoshida, S.; Miyagawa, S.; Fukushima, S.; Kawamura, T.; Kashiyama, N.; Ohashi, F.; Toyofuku, T.; Toda, K.; Sawa, Y. Maturation of human induced pluripotent stem cell-derived cardiomyocytes by soluble factors from human mesenchymal stem cells. Mol. Ther. 2018, 26, 2681-2695. [CrossRef]

86. Iwasaki, H.; Imamura, T.; Morino, K.; Shimosato, T.; Tawa, M.; Ugi, S.; Sakurai, H.; Maegawa, H.; Okamura, T. Microrna-494 plays a role in fiber type-specific skeletal myogenesis in human induced pluripotent stem cells. Biochem. Biophys. Res. Commun. 2015, 468, 208-213. [CrossRef]

87. Quattrocelli, M.; Swinnen, M.; Giacomazzi, G.; Camps, J.; Barthelemy, I.; Ceccarelli, G.; Caluwe, E.; Grosemans, H.; Thorrez, L.; Pelizzo, G.; et al. Mesodermal ipsc-derived progenitor cells functionally regenerate cardiac and skeletal muscle. J. Clin. Investig. 2015, 125, 4463-4482. [CrossRef]

88. Kondo, H.; Kim, H.W.; Wang, L.; Okada, M.; Paul, C.; Millard, R.W.; Wang, Y. Blockade of senescence-associated microrna-195 in aged skeletal muscle cells facilitates reprogramming to produce induced pluripotent stem cells. Aging Cell 2016, 15, 56-66. [CrossRef] [PubMed]

89. Hilton, I.B.; Gersbach, C.A. Enabling functional genomics with genome engineering. Genome Res. 2015, 25, 1442-1455. [CrossRef]

90. Turan, S.; Farruggio, A.P.; Srifa, W.; Day, J.W.; Calos, M.P. Precise correction of disease mutations in induced pluripotent stem cells derived from patients with limb girdle muscular dystrophy. Mol. Ther. 2016, 24, 685-696. [CrossRef]

91. Ikink, G.J.; Boer, M.; Bakker, E.R.M.; Vendel-Zwaagstra, A.; Klijn, C.; Ten Hoeve, J.; Jonkers, J.; Wessels, L.F.; Hilkens, J. Insertional mutagenesis in a her2-positive breast cancer model reveals eras as a driver of cancer and therapy resistance. Oncogene 2018, 37, 1594-1609. [CrossRef] [PubMed]

92. Bii, V.M.; Collins, C.P.; Hocum, J.D.; Trobridge, G.D. Replication-incompetent gammaretroviral and lentiviral vector-based insertional mutagenesis screens identify prostate cancer progression genes. Oncotarget 2018, 9, 15451-15463. [CrossRef] [PubMed] 
93. Howe, S.J.; Mansour, M.R.; Schwarzwaelder, K.; Bartholomae, C.; Hubank, M.; Kempski, H.; Brugman, M.H.; Pike-Overzet, K.; Chatters, S.J.; de Ridder, D.; et al. Insertional mutagenesis combined with acquired somatic mutations causes leukemogenesis following gene therapy of scid-x1 patients. J. Clin. Investig. 2008, 118, 3143-3150. [CrossRef] [PubMed]

94. Gaj, T.; Gersbach, C.A.; Barbas, C.F., 3rd. Zfn, talen, and crispr/cas-based methods for genome engineering. Trends Biotechnol. 2013, 31, 397-405. [CrossRef] [PubMed]

95. Merkert, S.; Martin, U. Targeted gene editing in human pluripotent stem cells using site-specific nucleases. Adv. Biochem. Eng. Biotechnol. 2018, 163, 169-186. [PubMed]

96. Guha, T.K.; Wai, A.; Hausner, G. Programmable genome editing tools and their regulation for efficient genome engineering. Comput. Struct. Biotechnol. J. 2017, 15, 146-160. [CrossRef] [PubMed]

97. Ran, F.A.; Hsu, P.D.; Lin, C.Y.; Gootenberg, J.S.; Konermann, S.; Trevino, A.E.; Scott, D.A.; Inoue, A.; Matoba, S.; Zhang, Y.; et al. Double nicking by rna-guided crispr cas9 for enhanced genome editing specificity. Cell 2013, 154, 1380-1389. [CrossRef]

98. Park, A.; Hong, P.; Won, S.T.; Thibault, P.A.; Vigant, F.; Oguntuyo, K.Y.; Taft, J.D.; Lee, B. Sendai virus, an rna virus with no risk of genomic integration, delivers crispr/cas9 for efficient gene editing. Mol. Ther. Methods Clin. Dev. 2016, 3, 16057. [CrossRef] [PubMed]

99. Aartsma-Rus, A.; Ginjaar, I.B.; Bushby, K. The importance of genetic diagnosis for duchenne muscular dystrophy. J. Med. Genet. 2016, 53, 145-151. [CrossRef]

100. Takeshima, Y.; Yagi, M.; Okizuka, Y.; Awano, H.; Zhang, Z.; Yamauchi, Y.; Nishio, H.; Matsuo, M. Mutation spectrum of the dystrophin gene in 442 duchenne/becker muscular dystrophy cases from one japanese referral center. J. Hum. Genet. 2010, 55, 379-388. [CrossRef]

101. Muntoni, F.; Torelli, S.; Ferlini, A. Dystrophin and mutations: One gene, several proteins, multiple phenotypes. Lancet Neurol. 2003, 2, 731-740. [CrossRef]

102. Filareto, A.; Parker, S.; Darabi, R.; Borges, L.; Iacovino, M.; Schaaf, T.; Mayerhofer, T.; Chamberlain, J.S.; Ervasti, J.M.; McIvor, R.S.; et al. An ex vivo gene therapy approach to treat muscular dystrophy using inducible pluripotent stem cells. Nat. Commun. 2013, 4, 1549. [CrossRef]

103. Kazuki, Y.; Hiratsuka, M.; Takiguchi, M.; Osaki, M.; Kajitani, N.; Hoshiya, H.; Hiramatsu, K.; Yoshino, T.; Kazuki, K.; Ishihara, C.; et al. Complete genetic correction of ips cells from duchenne muscular dystrophy. Mol. Ther. 2010, 18, 386-393. [CrossRef] [PubMed]

104. Kumar, M.; Keller, B.; Makalou, N.; Sutton, R.E. Systematic determination of the packaging limit of lentiviral vectors. Hum. Gene Ther. 2001, 12, 1893-1905. [CrossRef] [PubMed]

105. Zhang, Y.; Long, C.; Bassel-Duby, R.; Olson, E.N. Myoediting: Toward prevention of muscular dystrophy by therapeutic genome editing. Physiol. Rev. 2018, 98, 1205-1240. [CrossRef] [PubMed]

106. Zhu, P.; Wu, F.; Mosenson, J.; Zhang, H.; He, T.C.; Wu, W.S. Crispr/cas9-mediated genome editing corrects dystrophin mutation in skeletal muscle stem cells in a mouse model of muscle dystrophy. Mol. Ther. Nucleic Acids 2017, 7, 31-41. [CrossRef] [PubMed]

107. Ousterout, D.G.; Kabadi, A.M.; Thakore, P.I.; Perez-Pinera, P.; Brown, M.T.; Majoros, W.H.; Reddy, T.E.; Gersbach, C.A. Correction of dystrophin expression in cells from duchenne muscular dystrophy patients through genomic excision of exon 51 by zinc finger nucleases. Mol. Ther. 2015, 23, 523-532. [CrossRef] [PubMed]

108. Kyrychenko, V.; Kyrychenko, S.; Tiburcy, M.; Shelton, J.M.; Long, C.; Schneider, J.W.; Zimmermann, W.H.; Bassel-Duby, R.; Olson, E.N. Functional correction of dystrophin actin binding domain mutations by genome editing. JCI Insight 2017, 2. [CrossRef]

109. Amoasii, L.; Hildyard, J.C.W.; Li, H.; Sanchez-Ortiz, E.; Mireault, A.; Caballero, D.; Harron, R.; Stathopoulou, T.-R.; Massey, C.; Shelton, J.M.; et al. Gene editing restores dystrophin expression in a canine model of duchenne muscular dystrophy. Science 2018, 362, 86-91. [CrossRef]

110. Long, C.; Amoasii, L.; Mireault, A.A.; McAnally, J.R.; Li, H.; Sanchez-Ortiz, E.; Bhattacharyya, S.; Shelton, J.M.; Bassel-Duby, R.; Olson, E.N. Postnatal genome editing partially restores dystrophin expression in a mouse model of muscular dystrophy. Science 2016, 351, 400-403. [CrossRef]

111. Li, H.L.; Fujimoto, N.; Sasakawa, N.; Shirai, S.; Ohkame, T.; Sakuma, T.; Tanaka, M.; Amano, N.; Watanabe, A.; Sakurai, H.; et al. Precise correction of the dystrophin gene in duchenne muscular dystrophy patient induced pluripotent stem cells by talen and crispr-cas9. Stem Cell Rep. 2015, 4, 143-154. [CrossRef] [PubMed] 
112. Long, C.; Li, H.; Tiburcy, M.; Rodriguez-Caycedo, C.; Kyrychenko, V.; Zhou, H.; Zhang, Y.; Min, Y.L.; Shelton, J.M.; Mammen, P.P.A.; et al. Correction of diverse muscular dystrophy mutations in human engineered heart muscle by single-site genome editing. Sci. Adv. 2018, 4, eaap9004. [CrossRef]

113. Young, C.S.; Hicks, M.R.; Ermolova, N.V.; Nakano, H.; Jan, M.; Younesi, S.; Karumbayaram, S.; Kumagai-Cresse, C.; Wang, D.; Zack, J.A.; et al. A single crispr-cas9 deletion strategy that targets the majority of dmd patients restores dystrophin function in hipsc-derived muscle cells. Cell Stem Cell 2016, 18, 533-540. [CrossRef]

114. Iyombe-Engembe, J.-P.; Ouellet, D.L.; Barbeau, X.; Rousseau, J.; Chapdelaine, P.; Lagüe, P.; Tremblay, J.P. Efficient restoration of the dystrophin gene reading frame and protein structure in dmd myoblasts using the cindel method. Mol. Ther. Nucleic Acids 2016, 5, e283. [CrossRef]

115. Popplewell, L.; Koo, T.; Leclerc, X.; Duclert, A.; Mamchaoui, K.; Gouble, A.; Mouly, V.; Voit, T.; Paques, F.; Cedrone, F.; et al. Gene correction of a duchenne muscular dystrophy mutation by meganuclease-enhanced exon knock-in. Hum. Gene Ther. 2013, 24, 692-701. [CrossRef]

116. Bengtsson, N.E.; Hall, J.K.; Odom, G.L.; Phelps, M.P.; Andrus, C.R.; Hawkins, R.D.; Hauschka, S.D.; Chamberlain, J.R.; Chamberlain, J.S. Corrigendum: Muscle-specific crispr/cas9 dystrophin gene editing ameliorates pathophysiology in a mouse model for duchenne muscular dystrophy. Nat. Commun. 2017, 8, 16007. [CrossRef]

117. El Refaey, M.; Xu, L.; Gao, Y.; Canan, B.D.; Adesanya, T.M.A.; Warner, S.C.; Akagi, K.; Symer, D.E.; Mohler, P.J.; $\mathrm{Ma}$, J.; et al. In vivo genome editing restores dystrophin expression and cardiac function in dystrophic mice. Circ. Res. 2017, 121, 923-929. [CrossRef]

118. Nelson, C.E.; Hakim, C.H.; Ousterout, D.G.; Thakore, P.I.; Moreb, E.A.; Castellanos Rivera, R.M.; Madhavan, S.; Pan, X.; Ran, F.A.; Yan, W.X.; et al. In vivo genome editing improves muscle function in a mouse model of duchenne muscular dystrophy. Science 2016, 351, 403-407. [CrossRef] [PubMed]

119. Tabebordbar, M.; Zhu, K.; Cheng, J.K.W.; Chew, W.L.; Widrick, J.J.; Yan, W.X.; Maesner, C.; Wu, E.Y.; Xiao, R.; Ran, F.A.; et al. In vivo gene editing in dystrophic mouse muscle and muscle stem cells. Science 2016, 351, 407-411. [CrossRef] [PubMed]

120. Xu, L.; Park, K.H.; Zhao, L.; Xu, J.; El Refaey, M.; Gao, Y.; Zhu, H.; Ma, J.; Han, R. Crispr-mediated genome editing restores dystrophin expression and function in mdx mice. Mol. Ther. 2016, 24, 564-569. [CrossRef]

121. Colella, P.; Ronzitti, G.; Mingozzi, F. Emerging issues in aav-mediated in vivo gene therapy. Mol. Ther. Meth. Clin. Dev. 2017, 8, 87-104. [CrossRef]

122. Maggio, I.; Stefanucci, L.; Janssen, J.M.; Liu, J.; Chen, X.; Mouly, V.; Goncalves, M.A. Selection-free gene repair after adenoviral vector transduction of designer nucleases: Rescue of dystrophin synthesis in dmd muscle cell populations. Nucleic Acids Res. 2016, 44, 1449-1470. [CrossRef]

123. Maggio, I.; Liu, J.; Janssen, J.M.; Chen, X.; Goncalves, M.A. Adenoviral vectors encoding crispr/cas9 multiplexes rescue dystrophin synthesis in unselected populations of dmd muscle cells. Sci. Rep. 2016, 6, 37051. [CrossRef] [PubMed]

124. Zhang, Y.; Long, C.; Li, H.; McAnally, J.R.; Baskin, K.K.; Shelton, J.M.; Bassel-Duby, R.; Olson, E.N. Crispr-cpf1 correction of muscular dystrophy mutations in human cardiomyocytes and mice. Sci. Adv. 2017, 3, e1602814. [CrossRef]

125. Lattanzi, A.; Duguez, S.; Moiani, A.; Izmiryan, A.; Barbon, E.; Martin, S.; Mamchaoui, K.; Mouly, V.; Bernardi, F.; Mavilio, F.; et al. Correction of the exon 2 duplication in dmd myoblasts by a single crispr/cas9 system. Mol. Ther. Nucleic Acids 2017, 7, 11-19. [CrossRef] [PubMed]

126. Charville, G.W.; Cheung, T.H.; Yoo, B.; Santos, P.J.; Lee, G.K.; Shrager, J.B.; Rando, T.A. Ex vivo expansion and in vivo self-renewal of human muscle stem cells. Stem Cell Rep. 2015, 5, 621-632. [CrossRef] [PubMed]

127. Ding, Q.; Regan, S.N.; Xia, Y.; Oostrom, L.A.; Cowan, C.A.; Musunuru, K. Enhanced efficiency of human pluripotent stem cell genome editing through replacing talens with crisprs. Cell Stem Cell 2013, 12, 393-394. [CrossRef]

128. Tedesco, F.S.; Hoshiya, H.; D’Antona, G.; Gerli, M.F.; Messina, G.; Antonini, S.; Tonlorenzi, R.; Benedetti, S.; Berghella, L.; Torrente, Y.; et al. Stem cell-mediated transfer of a human artificial chromosome ameliorates muscular dystrophy. Sci. Transl. Med. 2011, 3, 96ra78. [CrossRef]

129. Dastidar, S.; Ardui, S.; Singh, K.; Majumdar, D.; Nair, N.; Fu, Y.; Reyon, D.; Samara, E.; Gerli, M.F.M.; Klein, A.F.; et al. Efficient crispr/cas9-mediated editing of trinucleotide repeat expansion in myotonic dystrophy patient-derived ips and myogenic cells. Nucleic Acids Res. 2018, 46, 8275-8298. [CrossRef] 
130. Papapetrou, E.P.; Schambach, A. Gene insertion into genomic safe harbors for human gene therapy. Mol. Ther. 2016, 24, 678-684. [CrossRef]

131. Oceguera-Yanez, F.; Kim, S.I.; Matsumoto, T.; Tan, G.W.; Xiang, L.; Hatani, T.; Kondo, T.; Ikeya, M.; Yoshida, Y.; Inoue, $\mathrm{H}$.; et al. Engineering the aavs1 locus for consistent and scalable transgene expression in human ipscs and their differentiated derivatives. Methods 2016, 101, 43-55. [CrossRef]

132. Wallen, M.C.; Gaj, T.; Barbas, C.F., 3rd. Redesigning recombinase specificity for safe harbor sites in the human genome. PLoS ONE 2015, 10, e0139123. [CrossRef] [PubMed]

133. Kodaka, Y.; Rabu, G.; Asakura, A. Skeletal muscle cell induction from pluripotent stem cells. Stem Cells Int. 2017, 2017, 1376151. [CrossRef]

134. Tanaka, A.; Woltjen, K.; Miyake, K.; Hotta, A.; Ikeya, M.; Yamamoto, T.; Nishino, T.; Shoji, E.; Sehara-Fujisawa, A.; Manabe, Y.; et al. Efficient and reproducible myogenic differentiation from human ips cells: Prospects for modeling miyoshi myopathy in vitro. PLoS ONE 2013, 8, e61540. [CrossRef]

135. Maffioletti, S.M.; Gerli, M.F.; Ragazzi, M.; Dastidar, S.; Benedetti, S.; Loperfido, M.; VandenDriessche, T.; Chuah, M.K.; Tedesco, F.S. Efficient derivation and inducible differentiation of expandable skeletal myogenic cells from human es and patient-specific ips cells. Nat. Protoc. 2015, 10, 941-958. [CrossRef]

136. Darabi, R.; Arpke, R.W.; Irion, S.; Dimos, J.T.; Grskovic, M.; Kyba, M.; Perlingeiro, R.C. Human es- and ips-derived myogenic progenitors restore dystrophin and improve contractility upon transplantation in dystrophic mice. Cell Stem Cell 2012, 10, 610-619. [CrossRef]

137. Shoji, E.; Woltjen, K.; Sakurai, H. Directed myogenic differentiation of human induced pluripotent stem cells. Meth. Mol. Biol. 2016, 1353, 89-99.

138. Cadiñanos, J.; Bradley, A. Generation of an inducible and optimized piggybac transposon system. Nucleic Acids Res. 2007, 35, e87. [CrossRef]

139. Wolfs, E.; Verfaillie, C.M.; Van Laere, K.; Deroose, C.M. Radiolabeling strategies for radionuclide imaging of stem cells. Stem Cell Rev. 2015, 11, 254-274. [CrossRef]

140. Kim, M.H.; Lee, Y.J.; Kang, J.H. Stem cell monitoring with a direct or indirect labeling method. Nucl. Med. Mol. Imaging 2016, 50, 275-283. [CrossRef]

141. Farruggio, A.P.; Bhakta, M.S.; du Bois, H.; Ma, J.; Michele, P.C. Genomic integration of the full-length dystrophin coding sequence in duchenne muscular dystrophy induced pluripotent stem cells. Biotechnol. J. 2017, 12. [CrossRef] [PubMed]

142. Holvoet, B.; Quattrocelli, M.; Belderbos, S.; Pollaris, L.; Wolfs, E.; Gheysens, O.; Gijsbers, R.; Vanoirbeek, J.; Verfaillie, C.M.; Sampaolesi, M.; et al. Sodium iodide symporter pet and bli noninvasively reveal mesoangioblast survival in dystrophic mice. Stem Cell Rep. 2015, 5, 1183-1195. [CrossRef] [PubMed]

143. Kristin, S.; Radojewski, P.; Tobias, W.; Georg, D. In vivo bioluminescence imaging-A suitable method to track mesenchymal stromal cells in a skeletal muscle trauma. Open Orthop. J. 2015, 9, 262-269.

144. Wolfs, E.; Holvoet, B.; Ordovas, L.; Breuls, N.; Helsen, N.; Schonberger, M.; Raitano, S.; Struys, T.; Vanbilloen, B.; Casteels, C.; et al. Molecular imaging of human embryonic stem cells stably expressing human pet reporter genes after zinc finger nuclease-mediated genome editing. J. Nucl. Med. 2017, 58, 1659-1665. [CrossRef] [PubMed]

145. Lee, A.S.; Tang, C.; Cao, F.; Xie, X.; van der Bogt, K.; Hwang, A.; Connolly, A.J.; Robbins, R.C.; Wu, J.C. Effects of cell number on teratoma formation by human embryonic stem cells. Cell Cycle 2009, 8, 2608-2612. [CrossRef]

146. Giacomazzi, G.; Holvoet, B.; Trenson, S.; Caluwe, E.; Kravic, B.; Grosemans, H.; Cortes-Calabuig, A.; Deroose, C.M.; Huylebroeck, D.; Hashemolhosseini, S.; et al. Micrornas promote skeletal muscle differentiation of mesodermal ipsc-derived progenitors. Nat. Commun. 2017, 8, 1249. [CrossRef] [PubMed]

147. Neyrinck, K.; Breuls, N.; Holvoet, B.; Oosterlinck, W.; Wolfs, E.; Vanbilloen, H.; Gheysens, O.; Duelen, R.; Gsell, W.; Lambrichts, I.; et al. The human somatostatin receptor type 2 as an imaging and suicide reporter gene for pluripotent stem cell-derived therapy of myocardial infarction. Theranostics 2018, 8, 2799-2813. [CrossRef]

(C) 2019 by the authors. Licensee MDPI, Basel, Switzerland. This article is an open access article distributed under the terms and conditions of the Creative Commons Attribution (CC BY) license (http://creativecommons.org/licenses/by/4.0/). 